\title{
Light dependence of phosphorus uptake by microorganisms in the subtropical North and South Pacific Ocean
}

\author{
Solange Duhamel ${ }^{1,2, *}$, Karin M. Björkman ${ }^{1}$, David M. Karl ${ }^{1}$ \\ ${ }^{1}$ Department of Oceanography, Center for Microbial Oceanography: Research and Education (C-MORE) and \\ School of Ocean \& Earth Science \& Technology (SOEST), University of Hawaii, 1000 Pope Road, Honolulu, Hawaii 96822, USA \\ ${ }^{2}$ Present address: Lamont-Doherty Earth Observatory (LDEO), Division of Biology and Paleo Environment, Columbia \\ University, PO Box 1000, 61 Route 9W, Palisades, New York 10964, USA
}

\begin{abstract}
Light and dark phosphate $\left(\mathrm{PO}_{4}{ }^{3-}\right)$ uptake rates were investigated in the North Pacific Subtropical Gyre (NPSG) and along a coastal to open ocean transect in the South Pacific Ocean. $\mathrm{PO}_{4}{ }^{3-}$ uptake rates were consistently higher when incubated in the light, but the ratio of uptake in the light and dark (L:D) decreased with depth. In the NPSG, the L:D ratio of euphotic-layer integrated $\mathrm{PO}_{4}{ }^{3-}$ uptake was $1.58 \pm 0.08( \pm \mathrm{SE}, \mathrm{n}=15$ profiles $)$, and the average L:D ratio was 1.60 $\pm 0.45( \pm \mathrm{SD}, \mathrm{n}=42)$ between 5 and $45 \mathrm{~m}$ and $1.25 \pm 0.70( \pm \mathrm{SD}, \mathrm{n}=28)$ between 150 and $175 \mathrm{~m}$. The L:D ratio was higher for the pigmented plankton-enriched size fractions ( 0.6 to $2 \mu \mathrm{m}$ and $>2 \mu \mathrm{m})$, but results were difficult to interpret at the oligotrophic stations where non-pigmented and pigmented plankton cell sizes overlapped. Group-specific measurements obtained using flow cytometric cell sorting demonstrated that Prochlorococcus $\mathrm{PO}_{4}{ }^{3-}$ uptake rates were higher when the samples were incubated under ambient light. Adenosine-5'-triphosphate (ATP) uptake by Prochlorococcus was also higher in the light for the uptake of both the terminal $\mathrm{PO}_{4}{ }^{3-}$ group $\left(\left[\gamma_{-}{ }^{33} \mathrm{P}\right] \mathrm{ATP}\right)$ and adenine moiety $\left(\left[2,8-{ }^{3} \mathrm{H}\right] \mathrm{ATP}\right)$. This could be the result of secondary uptake of $\mathrm{PO}_{4}{ }^{3-}$ and/or adenine after ATP cleavage by non-pigmented picoplankton. There was no significant difference in P-assimilation by non-pigmented picoplankton between light and dark incubated samples. Light dependence of phytoplankton $\mathrm{PO}_{4}{ }^{3-}$ uptake could thus influence the functioning of the microbial loop and the flows of matter and energy in marine environments by creating temporal patterns of resource utilization.
\end{abstract}

KEY WORDS: Light · Phosphorus uptake - Flow cytometry cell sorting · Picoplankton · Oligotrophic gyre

Resale or republication not permitted without written consent of the publisher

\section{INTRODUCTION}

Nutrient uptake by marine microbial communities is influenced by many factors, including cell size, composition, metabolism, and the surrounding environment (Cembella et al. 1984a,b, Sunda \& Huntsman 1997, Zehr \& Ward 2002, Litchman et al. 2004). The effect of light on nutrient uptake was first shown for nitrogen (MacIsaac \& Dugdale 1972, Bates 1976, MacIsaac 1978) and is now well docu- mented. However, the effect of light on phosphorus (P) uptake is not well established, and the few studies that have been conducted either in the lab or in the field have led to contradictory results (Perry 1976, Reshkin \& Knauer 1979). The uptake processes of bicarbonate, nitrate, ammonia, and phosphate $\left(\mathrm{PO}_{4}{ }^{3-}\right)$ differ in their responses to light (Nalewajko et al. 1986, Takamura et al. 1987, Dortch 1990). Thus, extrapolations from the wellstudied light effect on nitrogen uptake cannot be 
applied to P-uptake, and more field studies are necessary.

$\mathrm{P}$ is an essential element for all living organisms (Karl 2000) as a vital component of nucleic acids, cell membranes, and molecules involved in energy transduction (e.g. adenosine 5 '-triphosphate [ATP]). Marine microorganisms generally prefer dissolved inorganic P (DIP) in the form of $\mathrm{PO}_{4}{ }^{3-}$ (Cembella et al. 1984a, Cotner \& Wetzel 1992, Dyhrman et al. 2007), and DIP availability can limit primary and secondary production (Van Wambeke et al. 2002, Thingstad et al. 2005, Elser et al. 2007). Microorganisms can also use dissolved organic phosphorus (DOP), the importance of which has been increasingly recognized in P nutrition (Karl \& Björkman 2002, Mather et al. 2008, Lomas et al. 2010, Duhamel et al. 2011). Therefore, chemoand phototrophs are in competition for $\mathrm{P}$ when it is scarce (Thingstad et al. 1993, 1998). In theory, small picoplankton should be more efficient at nutrient capture due to their larger surface to volume ratio compared to larger cells, and experimental work generally confirms this prediction (see Bratbak \& Thingstad 1985). Light stimulation of $P$ uptake may offer a competitive advantage of phototrophy over chemotrophy, particularly when chemotrophic substrates and $\mathrm{P}$ are limiting. In heterogeneous natural populations of planktonic organisms, it is challenging to attribute $\mathrm{P}$ uptake to different taxonomic groups when using traditional filtration techniques, as their size spectra often overlap and hence do not allow for their unique physical separation (Friebele et al. 1978, Nalewajko \& Garside 1983, Li \& Dickie 1985, Tanaka et al. 2004, Duhamel \& Moutin 2009). Consequently, most studies on the effect of light on $\mathrm{PO}_{4}{ }^{3-}$ uptake have been on cultures (Jansson 1993, Donald et al. 1997, Riegman et al. 2000, Ahn et al. 2002, Kumar et al. 2009), and those conducted in natural environments have yielded contradictory results (Perry 1976, Reshkin \& Knauer 1979, Lemasson et al. 1980, Nalewajko \& Lee 1983, Nalewajko et al. 1986, Moutin et al. 2002, Litchman et al. 2004, Duhamel et al. 2006). To our knowledge, the effect of light on DOP utilization has not been assessed in natural microbial assemblages.

Recently, the cell sorting capacity of flow cytometry has been used to measure group-specific uptake rates of radiolabeled compounds such as amino acids, bicarbonate, $\mathrm{PO}_{4}{ }^{3-}$, and $\left[\gamma-\right.$ or $\left.\alpha{ }^{3}{ }^{33} \mathrm{P}\right] \mathrm{ATP}$ ( $\mathrm{Li}$ 1994, Lipschultz 1995, Michelou et al. 2007, Zubkov et al. 2007, Larsen et al. 2008, Mary et al. 2008, Casey et al. 2009). This technique provides a unique means to differentiate activities among microbial groups and to refine our understanding of element cycling within the microbial loop. The combination of flow cytometric sorting and radioisotopic tracer techniques is a promising approach to study the effect of light on P uptake in natural assemblages.

The aim of the present study was to assess the effect of sunlight on the utilization rates of DIP (as $\mathrm{PO}_{4}{ }^{3-}$ ) and DOP (using ATP; Karl \& Björkman 2002) by different picoplankton groups across a wide range of trophic conditions within the North Pacific Subtropical Gyre (NPSG) and the South Pacific (SP).

\section{MATERIALS AND METHODS}

\section{Station locations and incubation conditions}

We conducted a series of experiments designed to look at the impact of light on $\mathrm{P}$ assimilation in the NPSG (Hawaii Ocean Time-series [HOT] cruises from 2000 to 2001 and 2010 and the KM1016 cruise from 20 to 30 August 2010 at Stn ALOHA [A LongTerm Oligotrophic Habitat Assessment]; ancillary data available on the HOT-DOGS website: http:// hahana.soest.hawaii.edu/hot/hot-dogs/) and the SP (BiG RAPA cruise, Biogeochemical Gradients: Role in Arranging Planktonic Assemblages, 18 November to 14 December 2010). Three distinct nutrient regimes from the SP were studied during the BiG RAPA cruise: the coastal Chilean upwelling (Stn UP), the transition zone from eutrophic to oligotrophic waters (Stn TR), and the central oligotrophic portion of the SP Subtropical Gyre (SPSG; Stn GY). Station locations and their physical, chemical, and biological properties are described in Table 1. Samples were collected into acid-cleaned $(10 \% \mathrm{HCl})$ bottles rinsed 3 times with sample seawater prior to analysis or incubation. The photosynthetically active radiation (PAR) was determined using a Biospherical (QSP2300, S/N 4644) sensor mounted on the conductivitytemperature-density (CTD) rosette frame.

\section{Analytical measurements}

Samples for $\mathrm{PO}_{4}{ }^{3-}$ determinations were either placed into high-density polyethylene (HDPE) bottles and stored frozen for later analysis (HOT and KM1016 cruises) by the MAGnesium-Induced Coprecipitation method (MAGIC; Karl \& Tien 1992; detection limit of $2 \mathrm{nmol} \mathrm{l}^{-1}$ in our application) followed by the molybdenum blue reaction (Murphy \& Riley 1962) or analyzed on fresh samples on board (BiG RAPA cruise) using an auto-analyzer (Technicon AutoAnalyzer II, detection limit of $10 \mathrm{nmol} \mathrm{l}^{-1}$ ). 
Table 1. Station locations and their physical, chemical, and biological properties. CM: chlorophyll maximum depth, SST: sea surface temperature. $\mathrm{PO}_{4}{ }^{3-}$ levels are given for a depth corresponding to $50 \%$ photosynthetically active radiation (PAR). The integrated ( 0 to $100 \mathrm{~m}, 0$ to $42 \mathrm{~m}, 0$ to $112 \mathrm{~m}$, and 0 to $165 \mathrm{~m}$ for NPSG, UP, TR, and GY stations, respectively) cell abundances are given for non-pigmented picoplankton, Prochlorococcus, Synechococcus, and picoalgae (\%). NPSG: North Pacific Subtropical Gyre; UP: upwelling; TR: transition; GY: oligotrophic South Pacific Subtropical Gyre

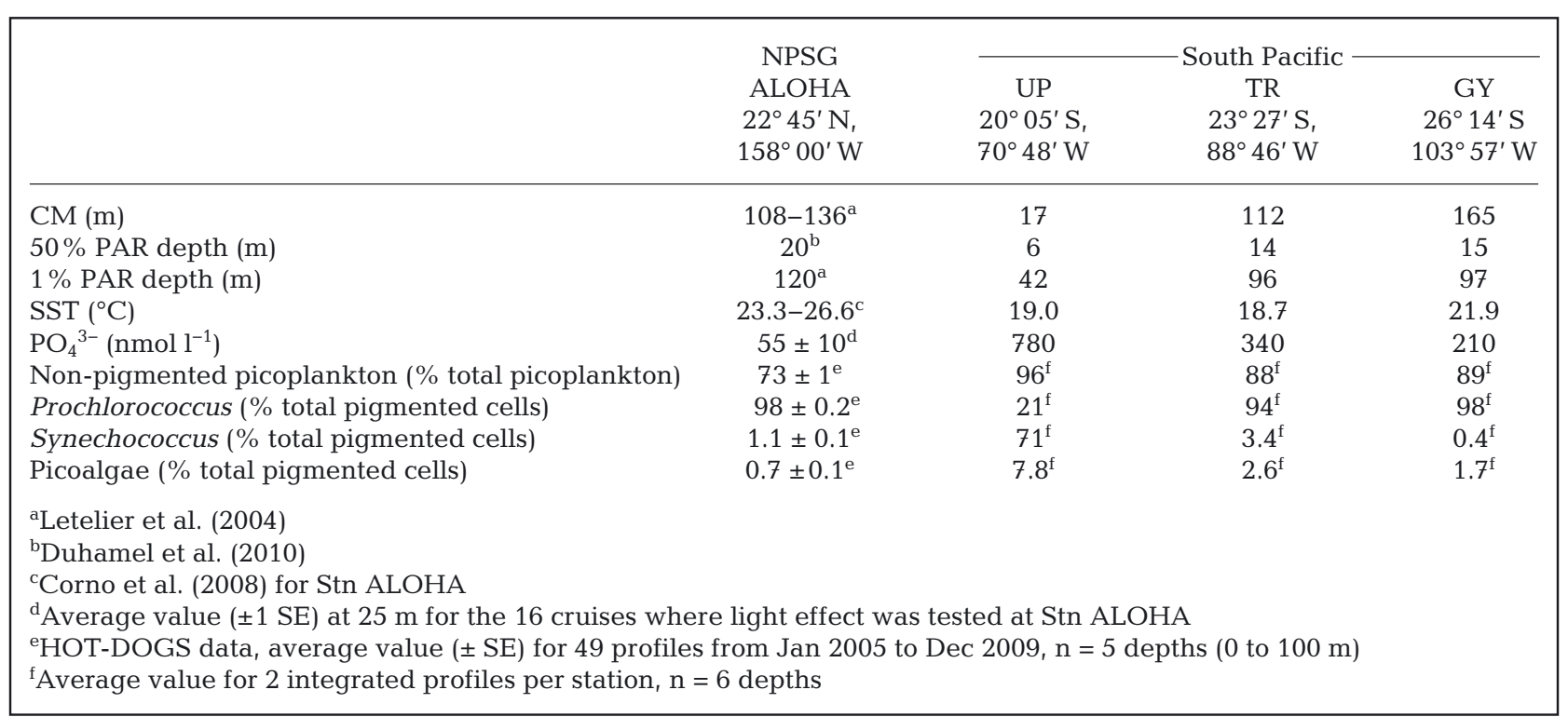

Microbial plankton groups (non-pigmented picoplankton, Prochlorococcus, Synechococcus, and picoalgae; Fig. 1) were enumerated using flow cytometry. To determine the fraction of each flow cytometrically identified group that passed through the different pore size filters used to assess size-fractionated Puptake rates, subsamples were taken before (total cell abundance) and after filtration through 0.6 and 2 $\mu \mathrm{m}$ polycarbonate (PC) membranes (47 mm diameter). Samples (whole water and filtrates) were fixed after filtration with paraformaldehyde (PFA, $0.2 \%$ final concentration), flash frozen in liquid nitrogen, and stored at $-80^{\circ} \mathrm{C}$ until analyzed. Flow cytometrically identified group abundances were determined using a Cytopeia Influx Mariner flow cytometer. Pigmented groups (Prochlorococcus, Synechococcus, and picoalgae) were enumerated in unstained samples using their natural chlorophyll fluorescence and forward scatter signatures (Fig. 1A). The high phycoerythrin signal in Synechococcus was used to distinguish this group from Prochlorococcus and picoalgae. To discriminate non-pigmented picoplankton, a $1 \mathrm{ml}$ aliquot was stained with SYBR green I (SG; $0.01 \%$ final concentration) and used to count the non-pigmented picoplankton and Prochlorococcus mixed populations (i.e. SG-stained particles group; Fig. 1B). Because of the overlap between the nonpigmented picoplankton and Prochlorococcus groups in surface samples after staining their nucleic acid
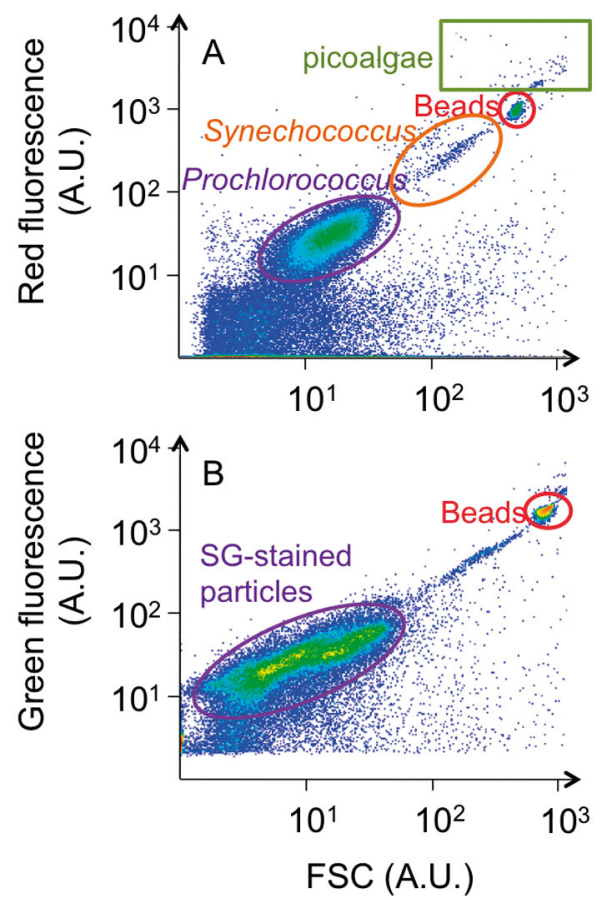

Fig. 1. Examples of cytograms for Stn ALOHA. (A) Unstained sample with pigmented groups (Prochlorococcus, Synechococcus, and picoalgae) characterized by their natural fluorescence in the red (i.e. chlorophyll a) and forward scatter (FSC) channels. (B) SYBR green I (SG) stained sample with the SG-stained particles group (i.e. non-pigmented picoplankton and Prochlorococcus) characterized by its fluorescence in the green (i.e. SG) and FSC channels.

Flow cytometry parameters are in arbitrary units (A.U.) 
content with SG, the non-pigmented picoplankton abundance was calculated by subtracting the Prochlorococcus cell numbers determined in the unstained aliquot from the SG-stained group abundance. By this criterion, any weakly naturally fluorescing Prochlorococcus undetected by autofluorescence would be considered to be part of the nonpigmented picoplankton assemblage, as would any DNA-containing dead cells. Flow cytometry data were analyzed with the FlowJo 7 software (Tree Star). To compare the data among samples and to determine the particles' relative fluorescence in the red, green and forward scatter channels (FSC), an internal standard of $1 \mu \mathrm{m}$ microspheres (Fluoresbrite, Polysciences) was added to each sample.

\section{Phosphorus uptake: depth profiles}

$\mathrm{PO}_{4}{ }^{3-}$ and ATP uptake rates were determined using the following tracers: ${ }^{32} \mathrm{PO}_{4}{ }^{3-}$ (orthophosphoric acid, carrier free, MP Biomedicals \#64014L, 267 TBq $\mathrm{mmol}^{-1}$ ) and $\left[\gamma_{-}{ }^{33} \mathrm{P}\right] \mathrm{ATP}$ (adenosine-5'-triphosphate, $>90 \%$ ATP $\left.\left[\gamma^{-33} \mathrm{P}\right], \# 35020,111 \mathrm{TBq} \mathrm{mmol}^{-1}\right)$ in the SP or $\left[\gamma_{-}{ }^{32} \mathrm{P}\right] \mathrm{ATP}\left(>90 \%\right.$ ATP $\left[\gamma_{-}{ }^{32} \mathrm{P}\right], \# 35020,259 \mathrm{TBq}$ $\left.\mathrm{mmol}^{-1}\right)$ in the NPSG as well as $\left[{ }^{3} \mathrm{H}\right] \mathrm{ATP}\left(\left[2,8{ }^{3} \mathrm{H}\right]\right.$, \#24009, $1.67 \mathrm{TBq} \mathrm{mmol}^{-1}$ ).

The $\mathrm{PO}_{4}{ }^{3-}$ total uptake rate $(>0.2 \mu \mathrm{m})$ was first examined over a $\sim 2$ yr period (2000 to 2001) in the NPSG (HOT cruises 113 to 115, 117, 119 to 122, 124 to 128 , and 131 to 132 ). Samples were routinely collected in triplicate bottles $(250 \mathrm{ml}, \mathrm{PC})$ from 8 depths $(5,25,45,75,100,125,150$, and $175 \mathrm{~m})$. Two of the bottles were incubated in the light and one in the dark, from dawn to dusk on an in situ, free-floating array. Dark samples were placed into black cloth bags and incubated alongside the clear bottles. The incubations were typically labeled to give a final ${ }^{32} \mathrm{P}$-activity of 75 to $150 \mathrm{kBq} \mathrm{l}^{-1}$. After retrieval of the array, the $\mathrm{P}$ incubations were stored in the dark at 22 to $24^{\circ} \mathrm{C}$ during the processing of the samples, usually $<2 \mathrm{~h}$. The seawater samples were filtered onto PC membranes $(0.2 \mu \mathrm{m}$ porosity, $25 \mathrm{~mm}$ diameter, Nuclepore) at low pressure $(<0.6$ bars). Filters were rinsed 3 times with $<0.2 \mu \mathrm{m}$ filtered seawater from the same sampling location. For whole water total radioactivity, $1 \mathrm{ml}$ of the seawater was collected from each incubation bottle. For total activity measurements, the filters and samples were placed into borosilicate glass scintillation vials, and $10 \mathrm{ml}$ of Aquasol II (Packard, \#NEF 952) was added for liquid scintillation counting (LSC).
The effect of light on size-fractionated $(0.2,0.6$, and $2 \mu \mathrm{m}$ porosity $\mathrm{PC}$ membranes, Millipore) $\mathrm{PO}_{4}{ }^{3-}$ and ATP uptake was examined in the NPSG (KM1016 and HOT-205 cruises) and the SP (BiG RAPA cruise). A sea-going flow cytometer was available on board the KM1016 and HOT-205 cruises, and the effect of light on $\mathrm{PO}_{4}{ }^{3-}$ and ATP uptake was analyzed by flow cytometry cell-sorting using the same samples as for the size-fractionated uptake. On the HOT-205 cruise, samples were incubated as described above. On the KM1016 and BiG RAPA cruises, samples were incubated in $75 \mathrm{ml}$ PC bottles in on-deck, blue-shielded Plexiglas (Arkema 2069, 1/4" thickness) incubators cooled with running surface seawater. One bottle was kept in the light (in mesh bags approximating the photosynthetically active radiation [PAR] level at which samples were taken: $50,25,15,7,3$, and $1 \%$ PAR or chlorophyll maximum [CM] when the sample depth was deeper than the 1\% PAR), and one bottle was kept in the dark (in a black cloth bag). Samples were typically labeled to give a final activity of 0.3 to $2.5 \mathrm{MBq}^{-1}, 0.016$ to $2.4 \mathrm{MBq}^{-1}$, and 1 to $2 \mathrm{MBq}^{-1}$, for ${ }^{32} \mathrm{PO}_{4}{ }^{3-},\left[\gamma_{-}{ }^{33} \mathrm{P}\right] \mathrm{ATP}$, and $\left[{ }^{3} \mathrm{H}\right] \mathrm{ATP}$, respectively. This corresponds to a maximum addition of $9.7 \mathrm{pmol} \mathrm{PO}_{4}{ }^{3-}$, $21.6 \mathrm{pmol}\left[\gamma_{-}{ }^{33} \mathrm{P}\right] \mathrm{ATP}$, and $1.5 \mathrm{nmol}\left[{ }^{3} \mathrm{H}\right] \mathrm{ATP}$, which represent trace amounts for ${ }^{32} \mathrm{PO}_{4}{ }^{3-}$ and $\left[\gamma_{-}{ }^{33} \mathrm{P}\right] \mathrm{ATP}$ but not for $\left[{ }^{3} \mathrm{H}\right] \mathrm{ATP}$. The highest activities were in samples destined for cell sorting. Samples were incubated for 4 to $8 \mathrm{~h}$ depending on expected turnover time and biomass. To stop the incubation, the samples were chased with non-radiolabeled $\mathrm{PO}_{4}{ }^{3-}(133 \mu \mathrm{M}$ of $\mathrm{KH}_{2} \mathrm{PO}_{4}$ or ATP, final concentration). On one occasion (HOT-205 cruise), the effect of sample fixation with PFA (0.2\% final concentration) was tested to stop the incubation prior to cell sorting. On average, $>70 \%$ of the signal measured at the time of sample fixation was lost within $12 \mathrm{~h}$ of sample preservation with PFA. We thus used a cold chase to stop incorporation of radiolabeled substrate as recommended by Talarmin et al. (2011). Samples for total and size-fractionated activities were vacuum filtered on PC membranes $(0.2,0.6$, and $2 \mu \mathrm{m}$ porosity, $25 \mathrm{~mm}$ diameter), rinsed (see above), then transferred into $6.5 \mathrm{ml}$ HDPE scintillation vials. An aliquot of $4 \mathrm{ml}$ of scintillation cocktail (Ultima Gold $^{\mathrm{TM}}$ LLT, Perkin Elmer) was added, and samples were counted on a Packard Tri-Carb ${ }^{\circledR}$ LSC or Beckman LS6500 in the NPSG and SP, respectively.

To determine group-specific activities, subsamples from the incubations used to determine total and size-fractionated activities were kept in the dark until sorting, using the same discrimination parameters as for cell enumeration (see 'Analytical measurements' above). Non-pigmented picoplankton 
and Prochlorococcus groups overlap in surface samples after SG staining. To separate uptake by Prochlorococcus from uptake by non-pigmented bacteria in the SG-stained samples, we measured total uptake in the SG-stained population and subtracted the uptake measured for Prochlorococcus in the nonstained sample. Samples were stained with SG for at least 30 min before sorting (Talarmin et al. 2011). The samples were sorted directly into scintillation vials without using a filter to avoid signal loss due to filtration (Talarmin et al. 2011). The background due to unincorporated radioactivity carried with the sorted cells was determined for each sample. To determine background values, fluorescent microspheres (1 $\mu \mathrm{m}$, Fluoresbrite, Polysciences) were added to each sample and sorted at the same time as Prochlorococcus and non-pigmented picoplankton populations into separate vials. The background activity (Bq bead ${ }^{-1}$ ) was subtracted from the sample activity (Bq cell ${ }^{-1}$ ). On average, 75000 to 100000 Prochlorococcus or 100000 to 200000 non-pigmented picoplankton were sorted into one scintillation vial. Then, $4 \mathrm{ml}$ of liquid scintillation cocktail was added, and samples were counted for radioactivity. In repeated sorts of the same sample, the variability in per cell activity was low $( \pm 2 \%)$ as was the variability among field replicates. The largest uncertainty (up to $\pm 10 \%$ ) was in the estimate of cell numbers $1^{-1}$ for surface Prochlorococcus, with typically dim Prochlorococcus fluorescence.

\section{Phosphorus uptake: uptake kinetics}

Light effects on $\mathrm{PO}_{4}{ }^{3-}$ and ATP uptake rates at different concentrations of $\mathrm{PO}_{4}{ }^{3-}$ and ATP were also assessed in the NPSG (KM1016 cruise at $25 \mathrm{~m}$, i.e. $\sim 50 \%$ PAR). Non-labeled $\mathrm{KH}_{2} \mathrm{PO}_{4}$ (range 0 to $150 \mathrm{nmol} \mathrm{l}^{-1} \mathrm{KH}_{2} \mathrm{PO}_{4}$ ) or ATP (range 0 to $50 \mathrm{nmol} \mathrm{l}^{-1}$ $\mathrm{ATP}$, equivalent to 0 to $150 \mathrm{nmol} \mathrm{l}^{-1} \mathrm{P}$ ) was added to samples with a constant radioactivity of $\sim 2.1$ and $\sim 2.4 \mathrm{MBq} 1^{-1}$ for ${ }^{32} \mathrm{PO}_{4}{ }^{3-}$ and $\left[\gamma_{-}{ }^{33} \mathrm{P}\right] \mathrm{ATP}$, respectively. An aliquot of each sample with $\mathrm{PO}_{4}{ }^{3-}$ added was placed into HDPE bottles and stored frozen for later analysis of $\mathrm{PO}_{4}{ }^{3-}$ concentration. The ambient $\mathrm{PO}_{4}{ }^{3-}$ concentration in the sample used for this experiment was $77 \mathrm{nmol} \mathrm{l}^{-1}$; therefore, the measured $\mathrm{PO}_{4}{ }^{3-}$ concentrations from 0 to $150 \mathrm{nmol}{ }^{-1} \mathrm{KH}_{2} \mathrm{PO}_{4}$ additions ranged from 77 to $232 \mathrm{nmol} \mathrm{l}^{-1}$ (see Fig. 5). For this experiment, ATP-uptake rates were calculated using a background ATP concentration of $0.2 \mathrm{nmol} \mathrm{l}^{-1}$ previously measured at Stn ALOHA at the same depth (Björkman \& Karl 2001, 2005).

\section{Calculation and statistical analysis}

The $\mathrm{PO}_{4}{ }^{3-}$ or ATP turnover times $(\mathrm{TT}, \mathrm{h})$ and uptake rates (nmol $\left.\mathrm{l}^{-1} \mathrm{~h}^{-1}\right)$ were calculated as follows: $\mathrm{TT}=\left(R_{\mathrm{t}} / R_{\mathrm{f}}\right)$, and $\mathrm{PO}_{4}{ }^{3-}$ or $\mathrm{ATP}$ uptake = $(S / \mathrm{TT})$, respectively, using the radioactivity on the filter or in the sorted population $\left(R_{\mathrm{f}}, \mathrm{Bq}^{-1} \mathrm{~h}^{-1}\right)$, the total tracer added $\left(R_{\mathrm{t}}, \mathrm{Bq}{ }^{-1}\right)$, and the $\mathrm{PO}_{4}{ }^{3-}$ or ATP concentration $\left(S\right.$, nmol $\left.l^{-1}\right)$. The L:D ratios were calculated from the turnover rate $\left(\mathrm{TR}, \mathrm{h}^{-1}\right)$ of the radiotracer measured in paired light and dark incubations, where $\mathrm{TR}=(1 / \mathrm{TT})$. Uptake rates were corrected for isotope dilution induced by either the ambient or added $\mathrm{PO}_{4}{ }^{3-}$ or ATP concentration. ATP uptake rates are based on $1 \mathrm{P}$ group from ATP, implying that the calculated uptake rate might be underestimated if all $3 \mathrm{P}$ are incorporated by the cells. Nevertheless, this does not impact the measured rate of the ATP pool turnover. Integrated values are between the surface (i.e. $0 \mathrm{~m}$ ) and either $1 \%$ PAR depth (Stns ALOHA [up to $125 \mathrm{~m}$ ] and UP) or the CM depth when 1\% PAR was shallower than the CM (i.e. Stns GY and TR; Table 1).

Results are reported as mean \pm standard deviation (SD) or standard error (SE) when specified (number of data: n). We used Sigmastat 3.1 (Systat Software) for the statistical analysis. Significance is reported where $\mathrm{p} \leq 0.05$.

\section{RESULTS}

\section{Environmental conditions}

Stn UP was located in the high-biomass, nutrientrich waters (Fig. 2A) off the coast of Chile, Stn GY in the central part of the oligotrophic SPSG (Fig. 2C), and Stn TR in the transition zone between UP and GY (Fig. 2B). The depth of the CM varied among these stations, ranging from $17 \mathrm{~m}$ at UP to $165 \mathrm{~m}$ at GY. To allow comparison among these stations, the sampling depths for this cruise were chosen based on PAR level (see 'Materials and methods') instead of the discrete depths used for NPSG at Stn ALOHA as for the HOT program. The NPSG and SPSG are considered to be oligotrophic, with low nutrients and biomass, $\mathrm{SST}>21.9^{\circ} \mathrm{C}$, and a $\mathrm{CM}>100 \mathrm{~m}$ (Table 1 ; Karl et al. 2001, Claustre et al. 2008). $\mathrm{PO}_{4}{ }^{3-}$ concentrations were variable in the NPSG, but even considering extreme values recorded in the upper $45 \mathrm{~m}$ at Stn ALOHA during the present study, ranging from the detection limit (i.e. $2 \mathrm{nmol}^{-1}$ ) to $113 \mathrm{nmol} \mathrm{l}^{-1}$ (see HOT-DOGS dataset), $\mathrm{PO}_{4}{ }^{3-}$ concentrations in the 


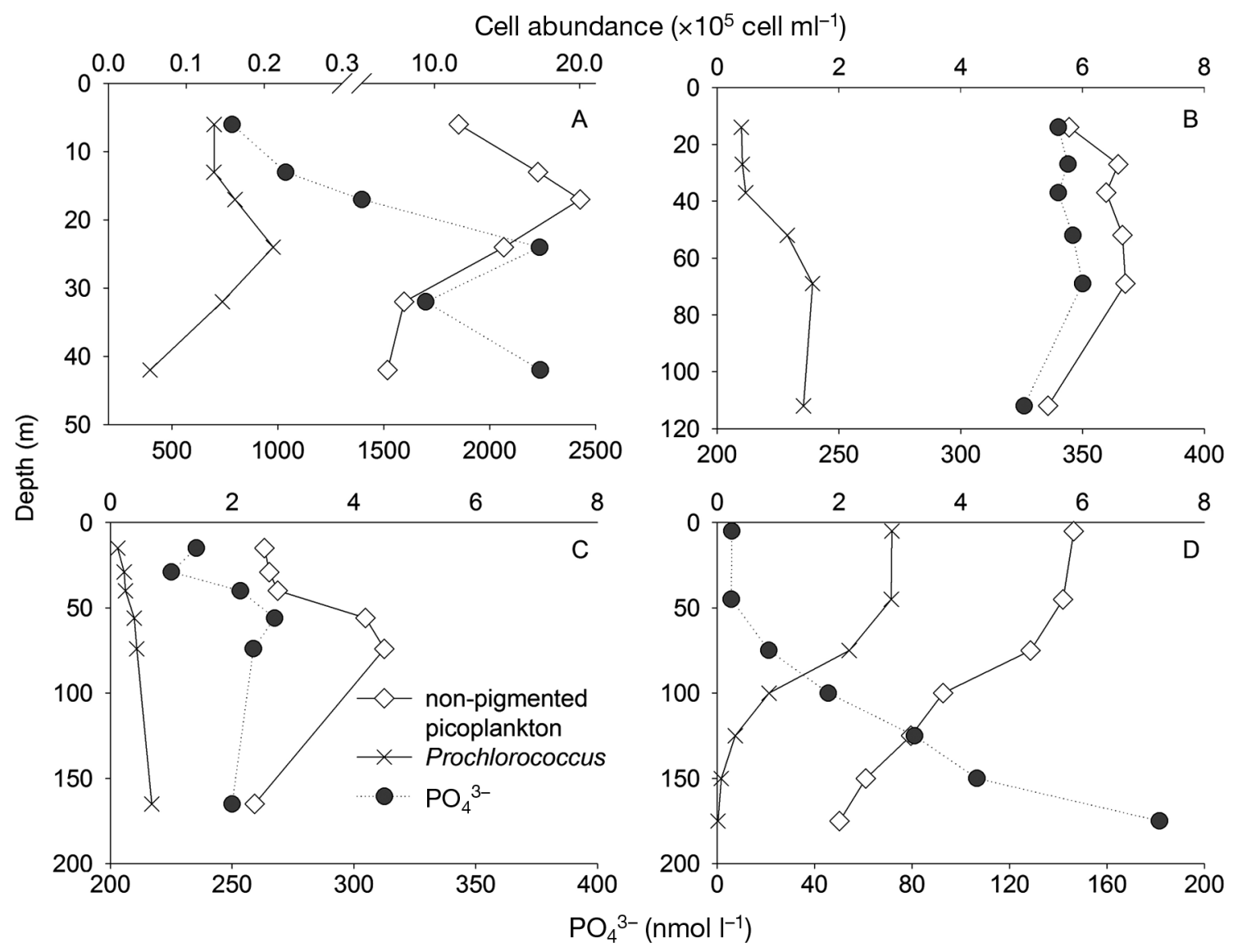

Fig. 2. Depth profiles of cell abundances (top $x$-axis) and $\mathrm{PO}_{4}{ }^{3-}$ concentrations (bottom $x$-axis) in the South Pacific at the (A) upwelling (Stn UP), (B) transition (Stn TR), and (C) oligotrophic South Pacific Subtropical Gyre (Stn GY) stations, and in (D) the North Pacific Subtropical Gyre (Stn ALOHA, HOT-205). Data are from single casts per station. Note the different depth, cell abundance and $\mathrm{PO}_{4}{ }^{3-}$ concentration scales

NPSG were the lowest among the 4 stations studied here (HOT cruise dataset for the present study: $53 \pm$ $31 \mathrm{nmol} \mathrm{l}^{-1}[ \pm 1 \mathrm{SE}, \mathrm{n}=48]$ between 5 and $45 \mathrm{~m}$ or 55 $\pm 10 \mathrm{nmol}^{-1}[ \pm 1 \mathrm{SE}, \mathrm{n}=16$ ] at $25 \mathrm{~m}$ [i.e. $\sim 50 \% \mathrm{PAR}]$ ), while all stations in the SPSG presented concentrations $>210 \mathrm{nmol} \mathrm{l}^{-1}$ (Fig. 2, Table 1). Microbial community composition at Stn UP was different from the other stations presented in this study, with Synechococcus dominating the picophytoplankton community $(71 \%$ of pigmented cells), while Prochlorococcus dominated at Stns TR and GY (94 and $98 \%$ of pigmented cells, respectively). The $\mathrm{PO}_{4}{ }^{3-}$ uptake rates in the light in the oligotrophic NPSG and GY were on average an order of magnitude lower than those measured at Stn UP (Fig. 3). At Stn TR, $\mathrm{PO}_{4}{ }^{3-}$ uptake rates were intermediate to rates measured in the NPSG, GY, and UP (Fig. 3B). There was no statistically significant correlation between $\mathrm{PO}_{4}{ }^{3-}$ concentration and $\mathrm{PO}_{4}{ }^{3-}$ uptake rate in the NPSG and SP ( $p>0.05)$.

\section{Effect of light on inorganic phosphorus uptake}

Total $\mathrm{PO}_{4}{ }^{3-}$ uptake: depth profiles

The effect of light on total (i.e. $>0.2 \mu \mathrm{m}$ ) $\mathrm{PO}_{4}{ }^{3-}$ uptake within the top $175 \mathrm{~m}$ of the water column was examined in the NPSG over a $2 \mathrm{yr}$ period (Fig. 3D). $\mathrm{PO}_{4}{ }^{3-}$ uptake rates integrated over the euphotic layer were $1.58 \pm 0.31(\mathrm{n}=15$ integrated profiles; $\mathrm{SE}=0.08$ ) times higher when incubated in the light than in the dark. The $\mathrm{L}: \mathrm{D}$ ratio of $\mathrm{PO}_{4}{ }^{3-}$ uptake rates decreased with depth, with $\mathrm{L}: \mathrm{D}=1.60$ $\pm 0.45(\mathrm{n}=42 ; \mathrm{SE}=0.07)$ between 5 and $45 \mathrm{~m}$ and $\mathrm{L}: \mathrm{D}=1.25 \pm 0.70(\mathrm{n}=28 ; \mathrm{SE}=0.11)$ between 150 and $175 \mathrm{~m} . \mathrm{PO}_{4}{ }^{3-}$ uptake rates were also higher in the light than in the dark at all 3 stations investigated in the $\mathrm{SP}$, and the $\mathrm{L}: \mathrm{D}$ ratios of euphotic layer integrated total (i.e. $>0.2 \mu \mathrm{m}$ ) $\mathrm{PO}_{4}{ }^{3-}$ uptake were 1.60, 1.38, and 1.15 at Stns UP, TR, and GY, respectively (Fig. 3). 


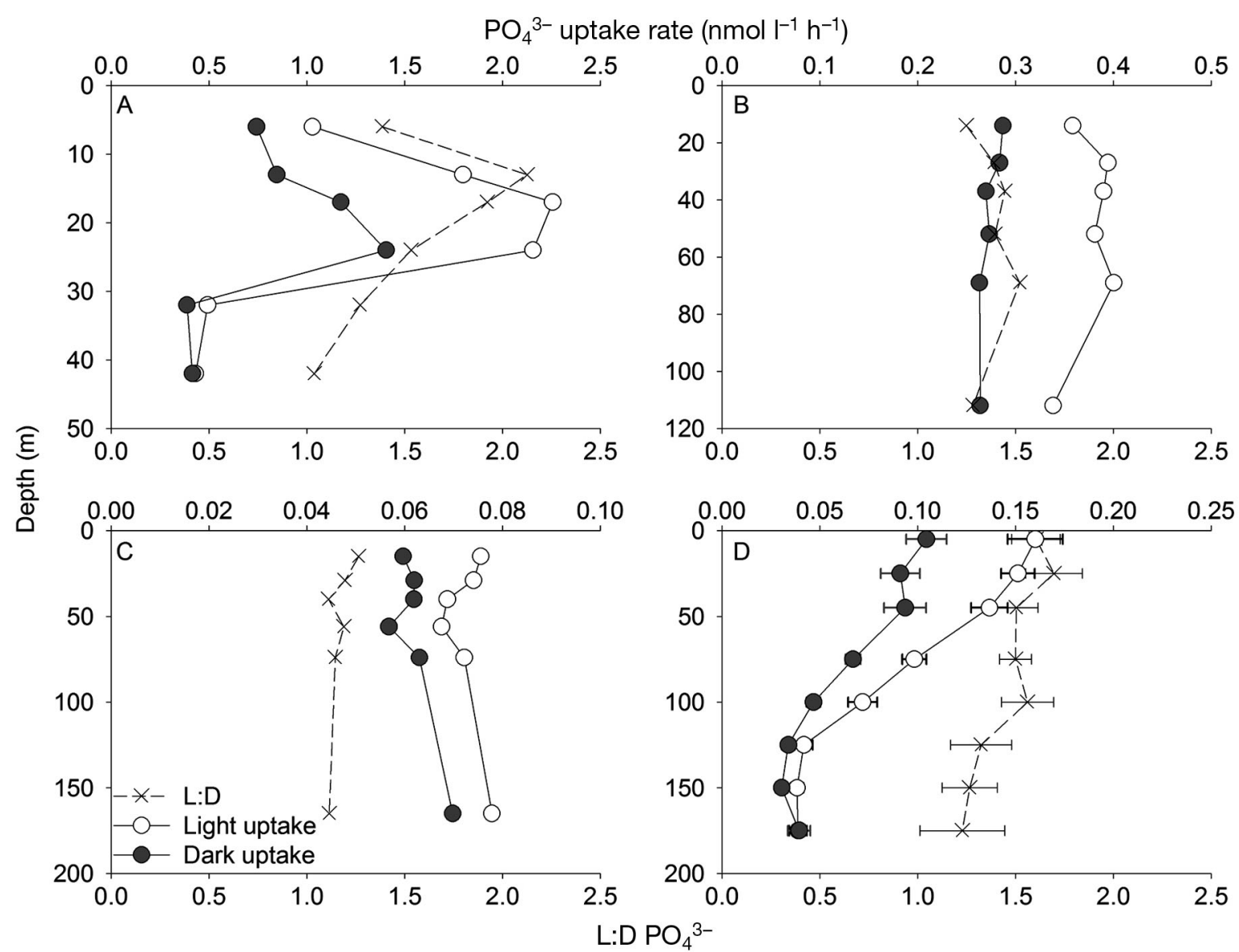

Fig. 3. Total $\mathrm{PO}_{4}{ }^{3-}$ uptake (top $\mathrm{X}$-axis) within the euphotic zone. Light and dark uptake and the light to dark $\mathrm{PO}_{4}{ }^{3-}$ uptake ratio (L:D, bottom $x$-axis) in the South Pacific at the (A) upwelling (Stn UP), (B) transition (Stn TR) and (C) oligotrophic South Pacific Subtropical Gyre (Stn GY) stations, and (D) the North Pacific Subtropical Gyre (NPSG) (Stn ALOHA). Profiles for NPSG are average values $\pm \mathrm{SE}(\mathrm{n}=15$ cruises). Note the different scales on both the $y$ and top $x$ axes

Size-fractionated and cell sorted $\mathrm{PO}_{4}{ }^{3-}$ uptake: depth profiles

In the SP, the effect of light on the 3 size fractions varied at the different stations (Fig. 4A-C) and was probably due to variations in microbial community composition (Table 1). At Stn UP, the mean effect of light on the $\mathrm{PO}_{4}{ }^{3-}$ uptake was larger in the 0.6 to $2 \mu \mathrm{m}$ and $>2 \mu \mathrm{m}$ fractions (L:D $=2.6 \pm 0.5, \mathrm{n}=6$ and $1.7 \pm 0.3, \mathrm{n}=6$, respectively) than in the 0.2 to $0.6 \mu \mathrm{m}$ fraction ( $\mathrm{L}: \mathrm{D}=1.0 \pm 0.1, \mathrm{n}=6$ ), although this difference was statistically significant only between the 0.6 to 2 and 0.2 to $0.6 \mu \mathrm{m}$ fractions (paired $t$-test, $\mathrm{p}<$ 0.05). At Stns TR and GY, $\mathrm{PO}_{4}{ }^{3-}$ uptake rates were higher in the light than in the dark in all 3 size fractions, including the 0.2 to $0.6 \mu \mathrm{m}$ fraction. Flow cytometric analysis of the filtrate fractions revealed that, at these latter stations, most of the Prochlorococcus cells passed through a $0.6 \mu \mathrm{m}$ filter $(90 \pm 5 \%, \mathrm{n}=24)$, so the light effect observed in the 0.2 to $0.6 \mu \mathrm{m}$ frac- tion could have arisen from these phototrophs. In the NPSG, Duhamel et al. (2010) reported that $>70 \%$ of the Prochlorococcus cells were retrieved in the $<0.6 \mu \mathrm{m}$ fraction at 15 to $20 \mathrm{~m}$ depth in summer. In contrast, at Stn UP, the $<0.6 \mu \mathrm{m}$ filtrate contained 23 $\pm 6 \%(\mathrm{n}=10)$ of the Prochlorococcus cells, indicating that Prochlorococcus cells were larger in the nutrient-rich coastal environment compared to the oligotrophic open ocean (data not shown).

The effect of light on $\mathrm{PO}_{4}{ }^{3-}$ uptake was also investigated in the NPSG during the HOT-205 cruise during which Prochlorococcus and non-pigmented picoplankton were sorted for group-specific uptake rates (Fig. 4D). The effect of light on non-pigmented picoplankton was low compared to that on Prochlorococcus (euphotic layer integrated L:D = 1.5 and 4.8, respectively), indicating that the effect of light observed in the total samples was mainly due to higher $\mathrm{PO}_{4}{ }^{3-}$ uptake by Prochlorococcus in the light than in the dark. 


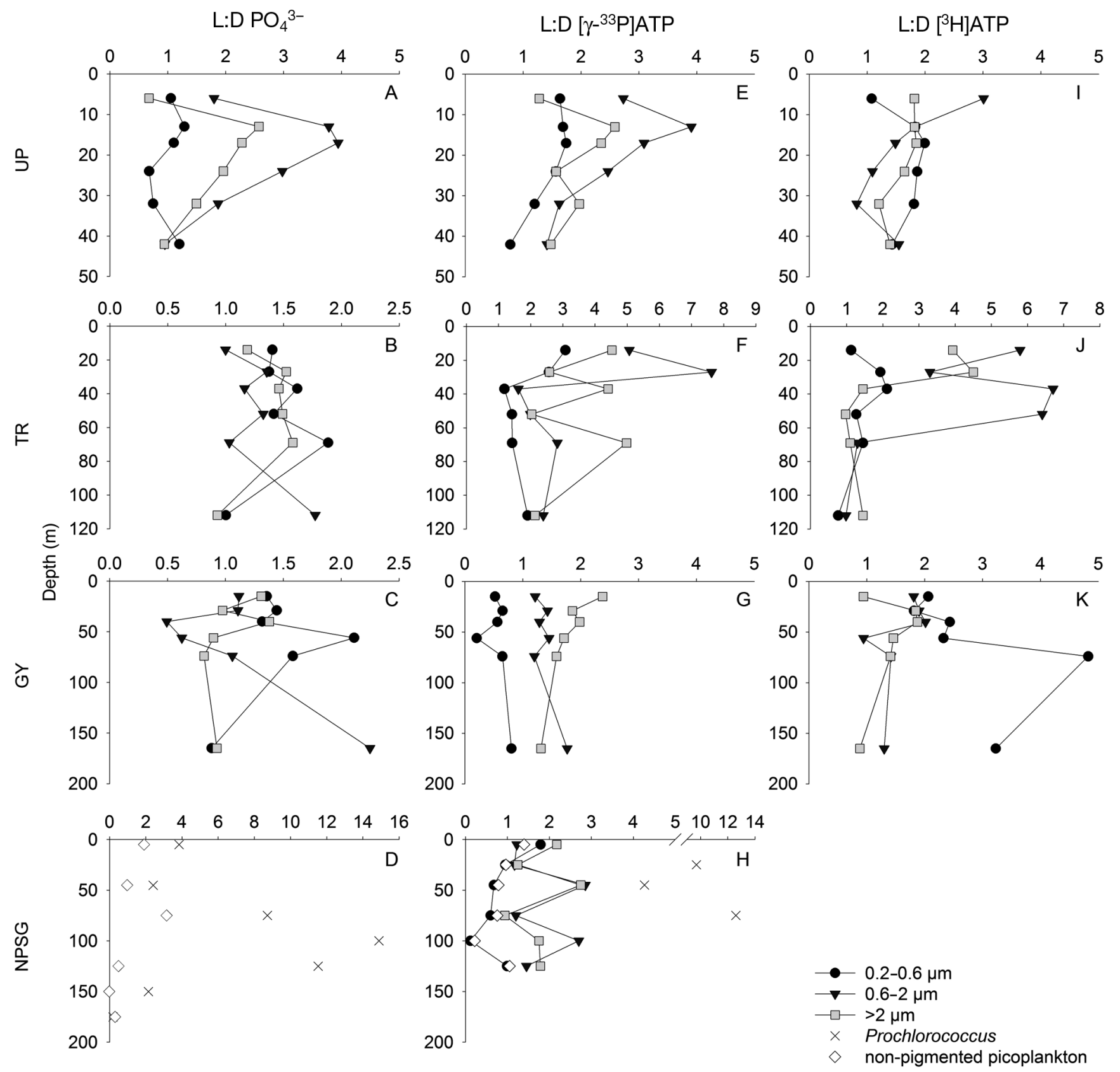

Fig. 4. Light to dark (L:D) uptake ratio of (A-D) $\mathrm{PO}_{4}{ }^{3-},(\mathrm{E}-\mathrm{H})\left[\gamma^{3}{ }^{3} \mathrm{P}\right] \mathrm{ATP}$, and $(\mathrm{I}-\mathrm{K})\left[{ }^{3} \mathrm{H}\right] \mathrm{ATP}$ in size-fractionated samples in the South Pacific at the $\left(A_{1}, \mathrm{E}, \mathrm{I}\right)$ upwelling (Stn UP), $(\mathrm{B}, \mathrm{F}, \mathrm{J})$ transition (Stn TR), and $(\mathrm{C}, \mathrm{G}, \mathrm{K})$ oligotrophic South Pacific Subtropical Gyre (Stn GY) stations, with cell-sorted samples (crosses: Prochlorococcus; diamonds: non-pigmented picoplankton) in $(\mathrm{D}, \mathrm{H})$ the North Pacific Subtropical Gyre (NPSG) (Stn ALOHA). Note the different depth and rate scales

$$
\mathrm{PO}_{4}{ }^{3-} \text { uptake kinetics }
$$

The addition of $\mathrm{PO}_{4}{ }^{3-}$ did not affect the $\mathrm{PO}_{4}{ }^{3-}$ uptake rate in the $25 \mathrm{~m}$ sample from NPSG (Fig. 5A-C), meaning that $\mathrm{PO}_{4}{ }^{3-}$ uptake systems were operating at saturating concentration in the well-lit NPSG. $\mathrm{PO}_{4}{ }^{3-}$ uptake rates in the Prochlorococcus group were 2.48 $\pm 0.15(\mathrm{n}=6)$ times higher in the light than in the dark (paired $t$-test), but there was no additive effect of light at increasing $\mathrm{PO}_{4}{ }^{3-}$ concentrations. Light had no significant effect on uptake by non-pigmented picoplankton at any $\mathrm{PO}_{4}{ }^{3-}$ concentrations tested (paired $t$ test, $\mathrm{p}=0.918) . \mathrm{PO}_{4}{ }^{3-}$ uptake rates in the light were significantly higher than in the dark in the 0.6 to $2 \mu \mathrm{m}$ and $>2 \mu \mathrm{m}$ fractions (paired $t$-test), and this difference increased with larger cells. 


\section{Effect of light on ATP uptake}

Size-fractionated and cell sorted ATP uptake: depth profiles

To examine the effect of light on ATP uptake, 2 radiolabeled forms of the substrate were used to track either the terminal $\mathrm{PO}_{4}{ }^{3-}\left(\left[\gamma_{-}{ }^{33} \mathrm{P}\right] \mathrm{ATP}\right)$ or the adenine $\left(\left[{ }^{3} \mathrm{H}\right] \mathrm{ATP}\right)$ moiety in the SP (Fig. $\left.4 \mathrm{E}-\mathrm{K}\right)$. The $\left[\gamma^{33} \mathrm{P}\right] \mathrm{ATP}$ and $\left[{ }^{3} \mathrm{H}\right] \mathrm{ATP}$ uptake rates were higher when incubated in the light than in the dark in most of the size fractions studied here.

In an additional experiment conducted in the NPSG, we compared both size-fractionated and cellsorted $\left[\gamma_{-}{ }^{33} \mathrm{P}\right] \mathrm{ATP}$ labeled samples (Fig. 4H). Interestingly, the L:D uptake ratio of $\left[\gamma^{-33} \mathrm{P}\right] \mathrm{ATP}$ obtained for the non-pigmented picoplankton population was not significantly different from the ratio obtained for the 0.2 to $0.6 \mu \mathrm{m}$ fraction (paired $t$-test). Nevertheless, Prochlorococcus L:D $\left[\gamma_{-}{ }^{33} \mathrm{P}\right] \mathrm{ATP}$ uptake was significantly greater ( 0 to $45 \mathrm{~m}$ integrated L:D $=7.84$ ) than the ratio measured in the 0.6 to $2 \mu \mathrm{m}$ and $>2 \mu \mathrm{m}$ fractions (analysis of variance, $\mathrm{p}<0.001$ ).

\section{ATP uptake kinetics}

Prochlorococcus $\left[\gamma_{-}{ }^{33} \mathrm{P}\right] \mathrm{ATP}$ uptake rate in the dark and in the light increased with the addition of nonradioactive ATP (Fig. 5D), while non-pigmented picoplankton saturated at $20 \mathrm{nmol} \mathrm{l}^{-1}$ of ATP added and then remained constant (average $\left[\gamma^{-33} \mathrm{P}\right] \mathrm{ATP}$ uptake rate $=0.07 \pm 0.01 \mathrm{nmol} \mathrm{l}^{-1} \mathrm{~h}^{-1}$ in both the light and the dark, after corrections for isotope dilutions; Fig. 5E). However, Prochlorococcus $\left[\gamma^{-33} \mathrm{P}\right]$ ATP uptake rate represented only 1 to $18 \%$ of the nonpigmented picoplankton uptake rate at the corresponding ATP concentrations when adjusted to cells $1^{-1}$. Similar to the $\mathrm{PO}_{4}{ }^{3-}$ uptake, $\left[\gamma^{-33} \mathrm{P}\right] \mathrm{ATP}$ uptake rate of Prochlorococcus was higher in the light than in the dark (paired $t$-test), while there was no statistical difference for non-pigmented picoplankton (paired $t$-test). The L:D $\left[\gamma^{33} \mathrm{P}\right]$ ATP uptake ratio in Prochlorococcus, non-pigmented picoplankton, and the 3 size fractions decreased with increasing ATP concentration added, up to $17 \mathrm{nmol} \mathrm{l}^{-1}$, and then remained constant. There was no significant difference between the L:D $\left[\gamma^{-33} \mathrm{P}\right] \mathrm{ATP}$ uptake in the 0.2 to
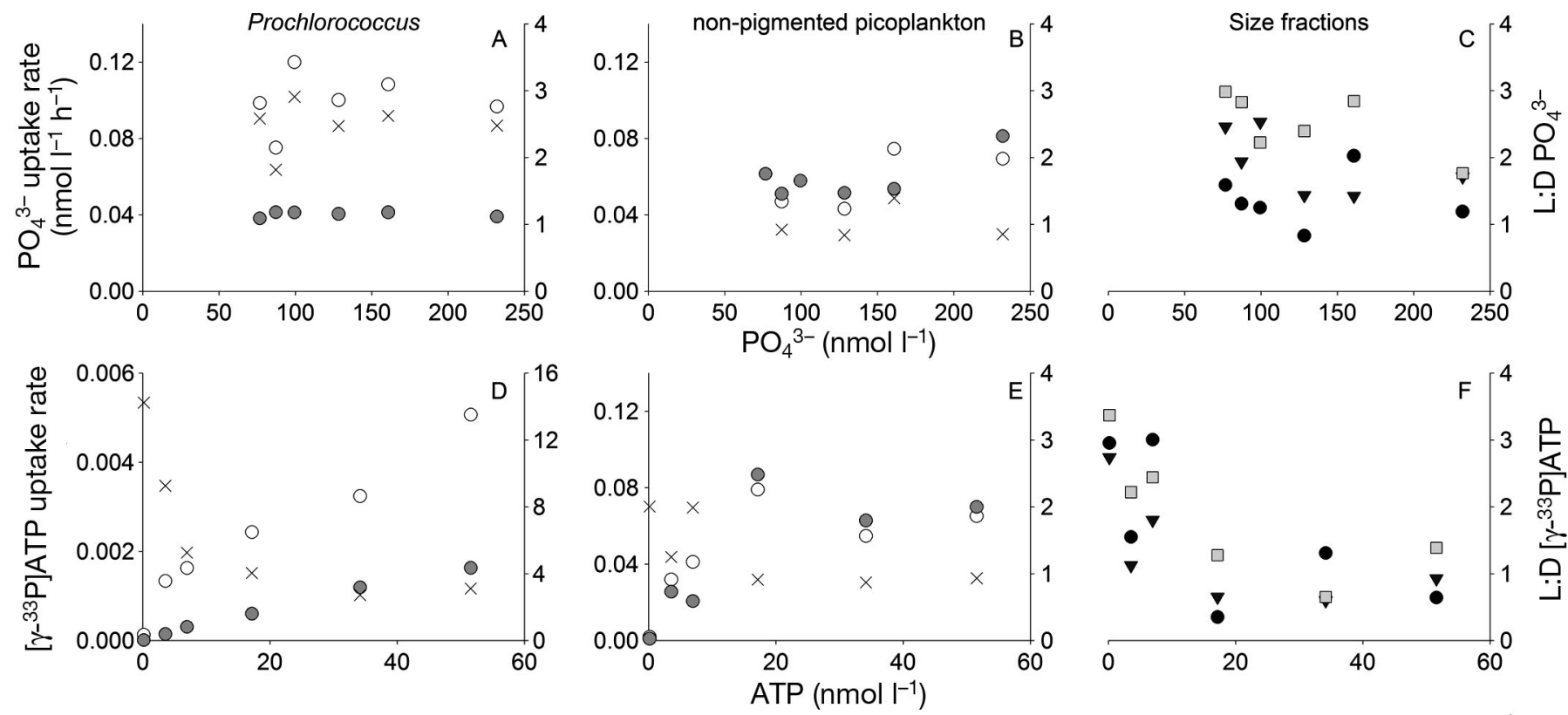

Fig. 5. $\mathrm{PO}_{4}{ }^{3-}$ and $\left[\gamma_{-}{ }^{33} \mathrm{P}\right] \mathrm{ATP}$ uptake rates (left $y$-axis) incubated in the light and in the dark at increasing concentrations of $\mathrm{PO}_{4}{ }^{3-}$ and ATP along with the light to dark uptake rate ratio (L:D, right $y$-axis) for $(\mathrm{A}, \mathrm{D})$ cell-sorted Prochlorococcus and $(\mathrm{B}, \mathrm{E})$ non-pigmented picoplankton groups. (C) $\mathrm{PO}_{4}{ }^{3-},(\mathrm{F})\left[\gamma_{-}{ }^{33} \mathrm{P}\right] \mathrm{ATP}$, and $(\mathrm{G})\left[{ }^{3} \mathrm{H}\right] \mathrm{ATP}$ uptake rates at increasing $\mathrm{PO}_{4}{ }^{3-}$ and ATP concentrations for size-fractionated samples (right $y$-axis) in the North Pacific Subtropical Gyre (Stn ALOHA)

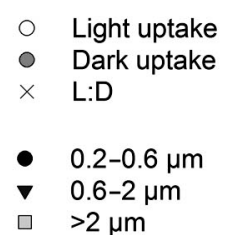

$\nabla \quad 0.6-2 \mu \mathrm{m}$

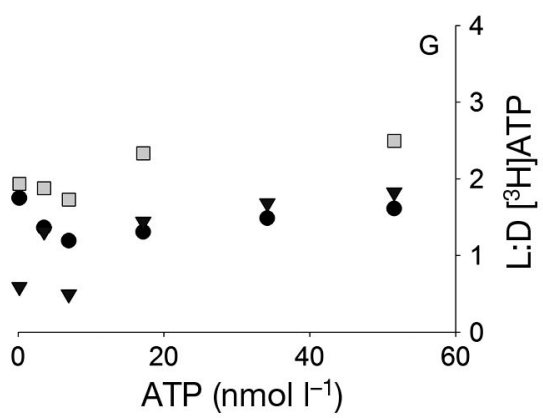


0.6 and 0.6 to $2 \mu \mathrm{m}$ fractions (paired $t$-test), while the ratios were higher in the $>2 \mu \mathrm{m}$ fraction (paired $t$ test).

The effect of ATP concentration on the L:D [ $\left.{ }^{3} \mathrm{H}\right] \mathrm{ATP}$ uptake was only assessed on size-fractionated populations (Fig. 5G) because results from cell sorting were unsuccessful due to low activities. The L:D ratios for [ $\left.{ }^{3} \mathrm{H}\right] \mathrm{ATP}$ uptake were significantly larger than 1 and did not vary with added ATP concentrations. Similar to the L:D $\left[\gamma^{-33}\right.$ P]ATP uptake, there was no significant difference between L:D [ $\left.{ }^{3} \mathrm{H}\right] \mathrm{ATP}$ uptake in the 0.2 to 0.6 and 0.6 to $2 \mu \mathrm{m}$ fractions, while the ratios in the $>2 \mu \mathrm{m}$ fraction were higher (paired $t$-tests).

\section{DISCUSSION}

This study covered a wide range of $\mathrm{PO}_{4}{ }^{3-}$ concentrations spanning from the low nutrient, prokaryotic picoplankton dominated North and South Pacific subtropical gyres to the high nutrient, large eukaryotic phytoplankton dominated coastal upwelling system off the coast of Chile (Karl et al. 2001, Claustre et al. 2008). $\mathrm{PO}_{4}{ }^{3-}$ concentrations in the SP increased from the center of the gyre to the coast of Chile as previously described by Moutin et al. (2008). The NPSG and SP are not currently P-limited (Moutin et al. 2008, Van Mooy \& Devol 2008, Duhamel et al. 2010), and as previously shown for the NPSG (Björkman et al. 2012), no correlation was found between $\mathrm{PO}_{4}{ }^{3-}$ concentration and uptake rate, indicating that at the time of our experiments, the ambient $\mathrm{PO}_{4}{ }^{3-}$ was sufficiently high to allow close to maximum or maximum uptake velocities by the microbial constituents. Nevertheless, longterm observations in the NPSG suggest that this system is shifting toward P-stress (Karl et al. 2001, Karl \& Letelier 2009). Recent studies have demonstrated that the NPSG is a dynamic system (Corno et al. 2007, 2008) where $\mathrm{PO}_{4}{ }^{3-}$ concentrations are variable (Karl \& Tien 1997) and may be temporally limiting for at least part of the microbial community (e.g. during or after a phytoplankton bloom; Watkins-Brandt et al. 2011). $\mathrm{PO}_{4}{ }^{3-}$ concentrations in the NPSG were the lowest among the 4 stations studied here, and values approaching the analytical detection limit of the method employed in our study (i.e. 2 nmol $\mathrm{l}^{-1}$ ) have occasionally been recorded in our surface samples (see HOT-DOGS dataset). Nevertheless, they did not reach limiting values at the time of the kinetic experiments, as illustrated by the kinetic signature for $\mathrm{PO}_{4}{ }^{3-}$ uptake, which was close to saturating concentration in unamended samples (Fig. 5A-C).

The light dependence of $\mathrm{P}$ uptake is not well documented, although previous studies have underlined the importance of this process for microbial nutrition and nutrient competition under dynamic light regimes (Reshkin \& Knauer 1979, Nalewajko \& Lee 1983, Litchman et al. 2004). Higher $\mathrm{PO}_{4}{ }^{3-}$ uptake rates in the light than in the dark have been observed in the northern Sargasso Sea, with factors (1.8x the dark rate) similar to those found in our study (Nalewajko \& Lee 1983). Even higher L:D ratios have been recorded at a station in the Strait of Georgia, British Columbia, Canada (2.7× dark uptake), a response the authors attributed to a P sufficient but light-limited status of the phytoplankton (Nalewajko \& Lee 1983). Our results also showed larger L:D ratios at Stn UP than at Stn GY ( $p<0.05)$. This result might be due to the higher growth rates in coastal regions (Stn UP) compared to the gyre (Duhamel et al. 2007). Indeed, higher biomass and growth rates might require enhanced $\mathrm{P}$ uptake in the light than in the dark since previous studies showed that phytoplankton division is synchronized to the L:D cycle and light availability controls cell division (Vaulot 1995).

In addition to confirming previous observations of higher $\mathrm{PO}_{4}{ }^{3-}$ uptake in the light than in the dark in marine phytoplankton, we also present the first evidence for group-specific $\mathrm{PO}_{4}{ }^{3-}$ uptake in samples from the natural environment. No previous studies on natural samples identified the organisms with higher $\mathrm{PO}_{4}{ }^{3-}$ uptake in the light. Most previous studies on the effect of light on $\mathrm{PO}_{4}{ }^{3-}$ uptake either used phytoplankton cultures (Jansson 1993, Donald et al. 1997, Riegman et al. 2000, Ahn et al. 2002, Kumar et al. 2009) or analyzed whole or size-fractionated water samples (Perry 1976, Reshkin \& Knauer 1979, Nalewajko \& Garside 1983, Nalewajko \& Lee 1983, Björkman et al. 2000). In contrast to past studies, we sorted samples into 2 targeted microbial groups (Prochlorococcus and non-pigmented picoplankton). This difference might explain the conflicting results and conclusions reached on this subject (Perry 1976, Reshkin \& Knauer 1979, Lemasson et al. 1980, Nalewajko \& Lee 1983, Moutin et al. 2002, Litchman et al. 2004, Duhamel et al. 2006). Because size-fractionated samples are composed of a mixture of microorganisms with a large range of metabolic traits, and because different functional groups may overlap in size, results from size-fractionated samples can be difficult to interpret. For example, our size-fraction- 
ated data showed higher $\mathrm{P}$ uptake in the light in the non-pigmented plankton-enriched fraction $(0.2$ to $0.6 \mu \mathrm{m})$, suggesting that ATP and $\mathrm{PO}_{4}{ }^{3-}$ uptake by chemotrophs respond to light. However, our groupspecific rates, obtained from the same samples, demonstrated no light effect in the sorted nonpigmented picoplankton, and a large effect in the pigmented picoplankton (here Prochlorococcus).

Our results indicate that phytoplankton maintain relatively high $\mathrm{P}$ uptake in the dark, which must be beneficial since P-transport is an energy-costly process. Phytoplankton capacity of maintaining $\mathrm{P}$ uptake in the dark might be an adaptation to changes in daily and seasonal light availability and also to vertical light and nutrient availability (Litchman et al. 2004). In oligotrophic P-limited environments, phototrophs can be in competition with chemotrophs for P (Thingstad et al. 1993, 1998). Using analytical techniques and simulations, Litchman et al. (2004) showed that dynamic light regimes could modify nutrient competition among phytoplankton and between phytoplankton and bacteria. In low-P environments, the effect of light-dependent $\mathrm{P}$ uptake by phytoplankton at ambient nutrient concentrations may influence competitive interactions among phytoplankton and bacteria and may allow for niche separation and coexistence of various strategies of resource utilization. If our findings are the result of light enhancement of cross-membrane transport, then higher P-uptake in the light in the Prochlorococcus population in the NPSG could offer them a competitive advantage over non-pigmented picoplankton when the P source becomes limiting.

Previous studies have returned conflicting results on the light dependence of nutrient uptake, with either a positive impact with increasing concentration (Perry 1976, Nalewajko \& Lee 1983) or a negative one (Healey 1977). We tested the impact of light on $\mathrm{PO}_{4}{ }^{3-}$ and ATP uptake at increasing substrate concentration in the NPSG. In these samples, while the maximum uptake rate of $\mathrm{PO}_{4}{ }^{3-}$ was not enhanced with increasing $\mathrm{PO}_{4}{ }^{3-}$ concentration, the $\left[\gamma^{33} \mathrm{P}\right] \mathrm{ATP}$ uptake increased with additions of ATP, indicating that the ATP uptake systems were not saturated at ambient concentrations (Björkman et al. 2012). The addition of ATP in these samples resulted in a decrease in the $\mathrm{L}: \mathrm{D}\left[\gamma_{-}{ }^{33} \mathrm{P}\right] \mathrm{ATP}$ uptake ratio, while the addition of $\mathrm{PO}_{4}{ }^{3-}$ did not affect the $\mathrm{L}: \mathrm{D} \mathrm{PO}_{4}{ }^{3-}$ uptake ratio. The $\mathrm{P}$ inventories in the NPSG are decreasing (Karl \& Letelier 2009), and in such an environment, light-enhanced $\mathrm{PO}_{4}{ }^{3-}$ uptake could be advantageous. Nevertheless, previous studies showed that light stimulation of $\mathrm{PO}_{4}{ }^{3-}$ uptake was larger for P-replete cells than P-limited cells, and the effect of light on P uptake appeared to be the result of $\mathrm{P}$ and light availability and also of the cellular P stores (see Nalewajko \& Lee 1983). This might explain the higher L:D ratio obtained in our UP station, although differences among taxonomic groups could also influence this result (see Litchman et al. 2004).

Results from cell sorting show that non-pigmented picoplankton may be the main contributors of $\left[\gamma^{33} \mathrm{P}\right]$ ATP utilization in the NPSG, while Prochlorococcus and non-pigmented picoplankton may incorporate $\mathrm{PO}_{4}{ }^{3-}$ at relatively similar rates (Björkman et al. 2012). In the North Atlantic Subtropical Gyre, Michelou et al. (2011) found that heterotrophic bacteria dominated both the uptake of $\mathrm{PO}_{4}{ }^{3-}$ and ATP in seawater, while uptake by Prochlorococcus and Synechococcus represented $<10 \%$ of the total. However, their incubations were conducted in the dark, which might have led to underestimates of the contribution from pigmented cells to $\mathrm{PO}_{4}{ }^{3-}$ and ATP uptake. Most studies assume that $\mathrm{P}$ uptake is linear over $24 \mathrm{~h}$ to calculate daily rates (see Duhamel et al. 2006). Since $\mathrm{P}$ uptake in phytoplankton appears to vary with light availability, daily $\mathrm{P}$ uptake rate calculation should take daily fluctuations into account. Because light availability varies throughout the day, daily rates would be affected by not only incubation in the light vs. in the dark but also by the time of the day and the incubation time length at which samples were incubated. More experiments are necessary to better assess (1) the relationship between hourly rates and daily rates of $\mathrm{P}$ uptake and (2) the diel variability of $\mathrm{P}$ uptake.

Previous results suggest that the light dependence of nutrient utilization varies according to the nutrient in question and the energy necessary to assimilate it. For example, nitrate uptake, which requires more energy than ammonium uptake, seems to be more affected by light (Litchman et al. 2004). In theory, ATP uptake should require more energy than $\mathrm{PO}_{4}{ }^{3-}$ uptake since ATP needs to be hydrolyzed outside the cell before $\mathrm{PO}_{4}{ }^{3-}$ or adenine uptake because bacteria do not take up intact ATP (Bengis-Garber \& Kushner 1982, Ammerman \& Azam 1985). Nevertheless, if the ATP bond energy can be utilized along with uptake of the $\mathrm{PO}_{4}{ }^{3-}$ or adenine released by ATP hydrolysis used in biosynthesis, there would be an energetic advantage to using ATP. The effect of light on ATP uptake has not been assessed previously. Our results showed that both $\left[\gamma_{-}{ }^{33} \mathrm{P}\right]$ and $\left[{ }^{3} \mathrm{H}\right] \mathrm{ATP}$ uptake rates were higher in the light, with generally higher L:D ratios at the surface than at 15\% PAR depth (Fig. 4). Since $\left[{ }^{3} \mathrm{H}\right] \mathrm{ATP}$ uptake was higher when samples 
were incubated in the light, incubations performed in the dark may lead to underestimation of ATP uptake, and those data may need to be reevaluated (Hodson et al. 1981, Michelou et al. 2011). Higher rates of $\left[{ }^{3} \mathrm{H}\right] \mathrm{ATP}$ uptake in the light by the pigmented plankton-enriched fractions $(0.6$ to $2 \mu \mathrm{m}$ and $>2 \mu \mathrm{m})$ may indicate that phototrophic cells increase their adenine uptake potentially to regulate de novo synthesis of purines when light is available. Yet, Karl (1981) showed that $\left[{ }^{3} \mathrm{H}\right] \mathrm{RNA}$ and $\left[{ }^{3} \mathrm{H}\right] \mathrm{DNA}$ production rates were not affected when incubated in the light or in the dark with $\left[{ }^{3} \mathrm{H}\right]$ adenine. Thus, higher $\left[\gamma^{3}{ }^{33} \mathrm{P}\right] \mathrm{ATP}$ and $\left[{ }^{3} \mathrm{H}\right] \mathrm{ATP}$ uptake rates in the light by pigmented picoplankton may be overestimated due to secondary uptake of ATP products hydrolyzed by nonpigmented picoplankton, which were responsible for the majority of $\left[\gamma_{-}{ }^{33} \mathrm{P}\right] \mathrm{ATP}$ uptake in the NPSG (Björkman et al. 2012). Indeed, Ammerman \& Azam (1991) showed that the fraction of $\mathrm{PO}_{4}{ }^{3-}$ uptake from ATP hydrolysis decreases with increasing ambient $\mathrm{PO}_{4}{ }^{3-}$ concentration.

The present study showed consistently higher $\mathrm{PO}_{4}{ }^{3-}$ uptake and ATP utilization for both the $\mathrm{PO}_{4}{ }^{3-}$ and the adenine moieties in the light than in the dark. Light dependence of P uptake is likely to influence diurnal variability in element stoichiometry of phytoplankton cells as well as ambient nutrient concentrations, which in turn may affect competitive interaction among phototrophs and chemotrophs (Kuipers et al. 2000, Litchman et al. 2004). Light dependence of phytoplankton P uptake could thus influence the functioning of the microbial loop and bacterial degradation of organic matter as well as the flow of matter and energy. Further studies will be necessary to better assess the effect of light on Putilization rates and improve our understanding of picoplankton niche-partitioning and the role of different functional groups in $\mathrm{P}$ cycling, e.g. in Prochlorococcus low-light and high-light ecotypes.

Acknowledgements. We thank the chief scientists of the Hawaii Ocean Time-series (HOT) program, Kilo Moana 1016 (KM1016), and BiG RAPA cruises for accommodating our needs on these cruises. We appreciate the efforts of the captains and crew of the RV 'Kilo Moana', RV 'Ka'imikai-OKanaloa', and RV 'Melville' and numerous colleagues in the Center for Microbial Oceanography: Research and Education (C-MORE) and HOT programs for their support. We thank J. C. Jennings, Jr. for providing the nutrient data from the BiG RAPA cruise and J. K. Doggett for his technical support with flow cytometry. Funds for this work were provided by the Gordon and Betty Moore Foundation's Marine Microbiology Initiative (D.M.K.) and the National Science Foundation (D.M.K., C-MORE grant EF0424599; Matthew J. Church, HOT grant 0926766).

\section{LITERATURE CITED}

Ahn CY, Chung AS, Oh HM (2002) Diel rhythm of algal phosphate uptake rates in P-limited cyclostats and simulation of its effect on growth and competition. J Phycol 38:695-704

Ammerman JW, Azam F (1985) Bacterial 5-nucleotidase in aquatic ecosystems: a novel mechanism of phosphorus regeneration. Science 227:1338-1340

> Ammerman JW, Azam F (1991) Bacterial 5'-nucleotidase activity in estuarine and coastal marine waters: characterization of enzyme activity. Limnol Oceanogr 36: $1427-1436$

Bates SS (1976) Effects of light and ammonium on nitrate uptake by two species of estuarine phytoplankton. Limnol Oceanogr 21:212-218

> Bengis-Garber C, Kushner DJ (1982) Role of membranebound 5'-nucleotidase in nucleotide uptake by the moderate halophile Vibrio costicola. J Bacteriol 149:808-815

$>$ Björkman KM, Karl DM (2001) A novel method for the measurement of dissolved adenosine and guanosine triphosphate in aquatic habitats: applications to marine microbial ecology. J Microbiol Methods 47:159-167

Björkman KM, Karl DM (2005) Presence of dissolved nucleotides in the North Pacific Subtropical Gyre and their role in cycling of dissolved organic phosphorus. Aquat Microb Ecol 39:193-203

> Björkman KM, Thomson-Bulldis AL, Karl DM (2000) Phosphorus dynamics in the North Pacific subtropical gyre. Aquat Microb Ecol 22:185-198

Björkman KM, Duhamel S, Karl DM (2012) Microbial group specific uptake kinetics of inorganic phosphate and adenosine-5'-triphosphate (ATP) in the North Pacific Subtropical Gyre. Frontiers Microbiol 3:189

> Bratbak G, Thingstad TF (1985) Phytoplankton-bacteria interactions: an apparent paradox? Analysis of a model system with both competition and commensalism. Mar Ecol Prog Ser 25:23-30

Casey JR, Lomas MW, Michelou VK, Dyhrman ST, Orchard ED, Ammerman JW, Sylvan JB (2009) Phytoplankton taxon-specific orthophosphate (Pi) and ATP utilization in the western subtropical North Atlantic. Aquat Microb Ecol 58:31-44

Cembella AD, Antia NJ, Harrison PJ (1984a) The utilization of inorganic and organic phosphorus compounds as nutrients by eukaryotic microalgae: a multidisciplinary perspective: part 1. Crit Rev Microbiol 10:317-391

Cembella AD, Antia NJ, Harrison PJ (1984b) The utilization of inorganic and organic phosphorus compounds as nutrients by eukaryotic microalgae: a multidisciplinary perspective: part 2. Crit Rev Microbiol 11:13-81

Claustre H, Sciandra A, Vaulot D (2008) Introduction to the special section bio-optical and biogeochemical conditions in the South East Pacific in late 2004: the BIOSOPE program. Biogeosciences 5:679-691

- Corno G, Karl DM, Church MJ, Letelier RM, Lukas R, Bidigare RR, Abbott MR (2007) Impact of climate forcing on ecosystem processes in the North Pacific Subtropical Gyre. J Geophys Res 112, C04021, doi:10:1029/2006JC 003730

> Corno G, Letelier RM, Abbott MR, Karl DM (2008) Temporal and vertical variability in photosynthesis in the North Pacific Subtropical Gyre. Limnol Oceanogr 53: 1252-1265

- Cotner JB, Wetzel RG (1992) Uptake of dissolved inorganic 
and organic phosphorus compounds by phytoplankton and bacterioplankton. Limnol Oceanogr 37:232-243

> Donald KM, Scanlan DJ, Carr NG, Mann NH, Joint I (1997) Comparative phosphorus nutrition of the marine cyanobacterium Synechococcus WH7803 and the marine diatom Thalassiosira weissflogii. J Plankton Res 19: 1793-1813

> Dortch Q (1990) The interaction between ammonium and nitrate uptake in phytoplankton. Mar Ecol Prog Ser 61: 183-201

> Duhamel S, Moutin T (2009) Carbon and phosphate incorporation rates of microbial assemblages in contrasting environments in the Southeast Pacific. Mar Ecol Prog Ser 375: 53-64

> Duhamel S, Zeman F, Moutin T (2006) A dual-labeling method for the simultaneous measurement of dissolved inorganic carbon and phosphate uptake by marine planktonic species. Limnol Oceanogr Methods 4: $416-425$

> Duhamel S, Moutin T, Van Wambeke F, Van Mooy B, Rimmelin P, Raimbault P, Claustre H (2007) Growth and specific P-uptake rates of bacterial and phytoplanktonic communities in the Southeast Pacific (BIOSOPE cruise). Biogeosciences 4:941-956

> Duhamel S, Dyhrman ST, Karl DM (2010) Alkaline phosphatase activity and regulation in the North Pacific Subtropical Gyre. Limnol Oceanogr 55:1414-1425

> Duhamel S, Björkman KM, Van Wambeke F, Moutin T, Karl DM (2011) Characterization of alkaline phosphatase activity in the North and South Pacific Subtropical Gyres: implications for phosphorus cycling. Limnol Oceanogr $56: 1244-1254$

> Dyhrman S, Ammerman JW, Van Mooy B (2007) Microbes and the marine phosphorus cycle. Oceanography 20: 110-116

- Elser JJ, Bracken MES, Cleland EE, Gruner DS and others (2007) Global analysis of nitrogen and phosphorus limitation of primary producers in freshwater, marine and terrestrial ecosystems. Ecol Lett 10:1135-1142

> Friebele ES, Correll DL, Faust MA (1978) Relationship between phytoplankton cell size and the rate of orthophosphate uptake: in situ observations of an estuarine population. Mar Biol 45:39-52

Healey FP (1977) Ammonium and urea uptake by some freshwater algae. Can J Bot 55:61-69

> Hodson RE, Maccubbin AE, Pomeroy LR (1981) Dissolved adenosine triphosphate utilization by free-living and attached bacterioplankton. Mar Biol 64:43-51

Jansson M (1993) Uptake, exchange and excretion of orthophosphate in phosphate-starved Scenedesmus quadricauda and Pseudomonas K7. Limnol Oceanogr 38: 1162-1178

Karl DM (1981) Simultaneous rates of ribonucleic acid and deoxyribonucleic acid syntheses for estimating growth and cell division of aquatic microbial communities. Appl Environ Microbiol 42:802-810

Karl DM (2000) Phosphorus, the staff of life. Nature 406: 31-32

Karl DM, Björkman KM (2002) Dynamics of DOP. In: Hansell DA, Carlson CA (eds) Biogeochemistry of marine dissolved organic matter. Elsevier Science, New York, NY, p 249-366

Karl DM, Letelier RM (2009) Seascape microbial ecology: habitat structure, biodiversity and ecosystem function. In: Levin SD (ed) Guide to ecology. Princeton University
Press, Princeton, NJ, p 488-500

> Karl DM, Tien G (1992) MAGIC: a sensitive and precise method for measuring dissolved phosphorus in aquatic environments. Limnol Oceanogr 37:105-116

Karl DM, Tien G (1997) Temporal variability in dissolved phosphorus concentrations in the subtropical North Pacific Ocean. Mar Chem 56:77-96

Karl DM, Bidigare RR, Letelier RM (2001) Long-term changes in phytoplankton community structure and productivity in the North Subtropical Gyre: the domain shift hypothesis. Deep-Sea Res II 48:1449-1470

> Kuipers B, van Noort GJ, Vosjan J, Herndl GJ (2000) Diel periodicity of bacterioplankton in the euphotic zone of the subtropical Atlantic Ocean. Mar Ecol Prog Ser 201: $13-25$

Kumar NA, Raja Rao VN, Rengasamy R (2009) Size differential growth and uptake kinetics of inorganic phosphate in some marine diatoms. J Phytol 1:75-85

- Larsen A, Tanaka T, Zubkov MV, Thingstad F (2008) Paffinity measurements of specific osmotroph populations using cell-sorting flow cytometry. Limnol Oceanogr Methods 6:355-363

> Lemasson L, Pages J, Cremou JL (1980) Inorganic phosphate uptake in a brackish tropical lagoon. Estuar Coast Mar Sci 11:547-561

Letelier RM, Karl DM, Abbott MR, Bidigare RR (2004) Light driven seasonal patterns of chlorophyll and nitrate in the lower euphotic zone of the North Pacific Subtropical Gyre. Limnol Oceanogr 49:508-519

Li WKW (1994) Primary production of prochlorophytes, cyanobacteria, and eukaryotic ultraphytoplankton: measurements from flow cytometric sorting. Limnol Oceanogr 39:169-175

Li WKW, Dickie PM (1985) Metabolic inhibition of size-fractionated marine plankton radiolabeled with amino acids, glucose, bicarbonate, and phosphate in the light and dark. Microb Ecol 11:11-24

> Lipschultz F (1995) Nitrogen-specific uptake rates of marine phytoplankton isolated from natural populations of particles by flow cytometry. Mar Ecol Prog Ser 123:245-258

Litchman E, Klausmeier CA, Bossard P (2004) Phytoplankton nutrient competition under dynamic light regimes. Limnol Oceanogr 49:1457-1462

Lomas MW, Burke AL, Lomas DA, Bell DW, Shen C, Dyhrman ST, Ammerman JW (2010) Sargasso Sea phosphorus biogeochemistry: an important role for dissolved organic phosphorus (DOP). Biogeosciences 7:695-710

> MacIsaac JJ (1978) Diel cycles of inorganic nitrogen uptake in a natural phytoplankton population dominated by Gonyaulax polyedra. Limnol Oceanogr 23:1-9

> MacIsaac JJ, Dugdale RC (1972) Interactions of light and inorganic nitrogen in controlling nitrogen uptake in the sea. Deep-Sea Res Oceanogr Abstr 19:209-232

- Mary I, Tarran GA, Warwick PE, Terry MJ, Scanlan DJ, Burkill PH, Zubkov MV (2008) Light enhanced amino acid uptake by dominant bacterioplankton groups in surface waters of the Atlantic Ocean. FEMS Microbiol Ecol 63:36-45

Mather RL, Reynolds SE, Wolff GA, Williams RG and others (2008) Phosphorus cycling in the North and South Atlantic Ocean subtropical gyres. Nat Geosci 1:439-443

Michelou VK, Cottrell MT, Kirchman DL (2007) Light-stimulated bacterial production and amino acid assimilation by cyanobacteria and other microbes in the North Atlantic Ocean. Appl Environ Microbiol 73:5539-5546 
Michelou VK, Lomas MW, Kirchman DL (2011) Phosphate and adenosine-5'-triphosphate uptake by cyanobacteria and heterotrophic bacteria in the Sargasso Sea. Limnol Oceanogr 56:323-332

Moutin T, Thingstad TF, Van Wambeke F, Marie D, Slawyk G, Raimbault P, Claustre H (2002) Does competition for nanomolar phosphate supply explain the predominance of the cyanobacterium Synechococcus? Limnol Oceanogr 47:1562-1567

Moutin T, Karl DM, Duhamel S, Rimmelin P, Raimbault P, Van Mooy BAS, Claustre H (2008) Phosphate availability and the ultimate control of new nitrogen input by nitrogen fixation in the tropical Pacific Ocean. Biogeosciences 5:95-109

> Murphy J, Riley J (1962) A modified single solution method for the determination of phosphate in natural waters. Anal Chim Acta 27:31-36

Nalewajko C, Garside C (1983) Methodological problems in the simultaneous assessment of photosynthesis and nutrient uptake in phytoplankton as functions of light intensity and cell size. Limnol Oceanogr 28:591-597

> Nalewajko C, Lee K (1983) Light stimulation of phosphate uptake in marine phytoplankton. Mar Biol 74:9-15

Nalewajko C, Paul B, Lee K, Shear H (1986) Light history, phosphorus status, and the occurrence of light stimulation or inhibition of phosphate uptake in Lake Superior phytoplankton and bacteria. Can J Fish Aquat Sci 43:329-335

> Perry MJ (1976) Phosphate utilization by an oceanic diatom in phosphorus-limited chemostat culture and in the oligotrophic waters of the central North Pacific. Limnol Oceanogr 21:88-105

Reshkin SJ, Knauer GA (1979) Light stimulation of phosphate uptake in natural assemblages of phytoplankton. Limnol Oceanogr 24:1121-1124

Riegman R, Stolte W, Noordeloos AAM, Slezak D (2000) Nutrient uptake and alkaline phosphatase (EC 3:1:3:1) activity of Emiliania huxleyi (Prymnesiophyceae) during growth under $\mathrm{N}$ and $\mathrm{P}$ limitation in continuous cultures. J Phycol 36:87-96

Sunda WG, Huntsman SA (1997) Interrelated influence of iron, light and cell size on marine phytoplankton growth. Nature 390:389-392

Takamura N, Iwakuma T, Yasuno M (1987) Uptake of ${ }^{13} \mathrm{C}$ and ${ }^{15} \mathrm{~N}$ (ammonium, nitrate and urea) by Microcystis in

Editorial responsibility: Josep Gasol,

Barcelona, Spain
Lake Kasumigaura. J Plankton Res 9:151-165

Talarmin A, Van Wambeke F, Duhamel S, Catala P, Moutin T, Lebaron P (2011) Improved methodology to measure taxon-specific phosphate uptake in live and unfiltered samples. Limnol Oceanogr Methods 9:443-453

Tanaka T, Rassoulzadegan F, Thingstad TF (2004) Orthophosphate uptake by heterotrophic bacteria, cyanobacteria, and autotrophic nanoflagellates in Villefranche Bay, northwestern Mediterranean: vertical, seasonal, and short-term variations of the competitive relationship for phosphorus. Limnol Oceanogr 49:1063-1072

> Thingstad TF, Skjoldal EF, Bohne RA (1993) Phosphorus cycling and algal-bacterial competition in Sandsfjord, western Norway. Mar Ecol Prog Ser 99:239-259

Thingstad TF, Zweifel UL, Rassoulzadegan F (1998) P limitation of heterotrophic bacteria and phytoplankton in the northwest Mediterranean. Limnol Oceanogr 43:88-94

Thingstad TF, Krom MD, Mantoura RFC, Flaten GAF and others (2005) Nature of phosphorus limitation in the ultraoligotrophic eastern Mediterranean. Science 309: 1068-1071

> Van Mooy B, Devol AH (2008) Assessing nutrient limitation of Prochlorococcus in the North Pacific subtropical gyre by using an RNA capture method. Limnol Oceanogr 53: 78-88

Van Wambeke F, Christaki U, Giannakourou A, Moutin T, Souvemerzoglou K (2002) Longitudinal and vertical trends of bacterial limitation by phosphorus and carbon in the Mediterranean Sea. Microb Ecol 43:119-133

Vaulot D (1995) The cell cycle of phytoplankton: coupling cell growth to population growth. In: Joint I (ed) Molecular ecology of aquatic microbes. NATO ASI Series G, Vol 38. Springer-Verlag, Berlin, p 303-322

Watkins-Brandt K, Letelier R, Spitz Y, Church M, Böttjer D, White A (2011) Addition of inorganic or organic phosphorus enhances nitrogen and carbon fixation in the oligotrophic North Pacific. Mar Ecol Prog Ser 432:17-29

$>$ Zehr JP, Ward BB (2002) Nitrogen cycling in the ocean: new perspectives on processes and paradigms. Appl Environ Microbiol 68:1015-1024

Zubkov MV, Mary I, Malcolm E, Woodward S and others (2007) Microbial control of phosphate in the nutrientdepleted North Atlantic subtropical gyre. Environ Microbiol 9:2079-2089

Submitted: August 4, 2011; Accepted: August 22, 2012

Proofs received from author(s): October 25, 2012 